\title{
A Mirror to the Eyes of the Mind. Metaphor in Otto van Veen's Amoris Divini Emblemata (Antwerp 1615)
}

\author{
Peter Boot
}

\begin{abstract}
The paper will give an account of metaphorical processes in Otto van Veen's Amoris Divini Emblemata (Antwerp 1615). It argues that, among other things, the shared contextual metaphors in picture and text are what makes the book a coherent whole. Embedding of a metaphor in an allegorical setting creates the possibility for communicating complex attitudes towards the metaphorical objects. Because of this, the density of meaning in the book may be larger than hitherto recognized.

The allegorical setting where Divine Love points out a metaphorical object to the soul mimics the communicative situation where the implied author uses emblem (or book) to address the reader. Thus, the metaphors do not just represent properties of love but also reflect the guidance to the soul that the book aspires to provide.
\end{abstract}

\section{Introduction}

In Die Liebesemblematik des Otto van Veen Ms. Buschhoff states 'daß sich Van Veens Liebesemblemkunst durch eine besonders konkrete Anschaulichkeit und neuartige Verständlichkeit auszeichnet, da sie vielfach metaforisch verfährt'. ${ }^{1}$ This paper will give a partial account of this metaphorical process in Amoris Divini Emblemata. ${ }^{2}$ Ms. Buschhoff thoroughly explains many of the metaphors that Vaenius employs, and the traditions from which they derive. She largely ignores, however, the mutual connections between many of these metaphors. I will argue that to some extent at least the book's coherence is attributable to the coherence of the metaphors it employs. To arrive at a better understanding of this coherence we should, among other things, pay more attention to the Hintergrundbildlichkeit, which Ms. Buschhoff discusses only briefly. ${ }^{3}$ The metaphors that provide the visual, but also literary, context to each emblem's central metaphor do largely define the web of interrelated meanings that create the book's overall significance.

The book itself will not need a long introduction. After his earlier book of secular love emblems, Otto van Veen published his religious emblem book in Antwerp in 1615. The book contains sixty emblems, with figures on the right page, texts on the left; for each emblem, there is a group of quotations in Latin, from the Bible and the church fathers, and three epigrams, in Spanish, Dutch and French. Each of the emblems, except the first, shows the protagonists Amor Divinus and Anima, Divine Love and the soul, involved in a symbolic action that represents a stage on the soul's journey towards heaven or God.

A look at the emblem MeNTIS SOL AMOR DEI ${ }^{4}$ will show how the role of metaphor in Amoris Divini Emblemata goes far beyond the presence of a metaphorical object or activity in the heart of the pictura. After this introduction, I will discuss my understanding of what a metaphor is, and mention a number of the recurring metaphors that are introduced in the first few emblems of the book. Then, in a discussion of a sample of emblems, I will examine some

\footnotetext{
${ }^{1}$ A. Buschhoff. Die Liebesemblematik des Otto van Veen. Die Amorum Emblemata (1608) und die Amoris Divini Emblemata (1615) (Bremen, 2004), 292.

${ }^{2}$ Otto van Veen, Amoris Divini Emblemata (Antwerp : M. Nutius and J. Meursius, 1615, $4^{\circ}$ ). The book is

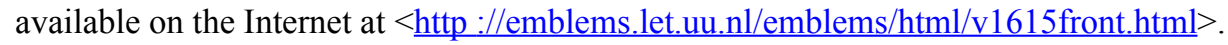

${ }^{3}$ A. Buschhoff, op. cit., 287.

4 'The love of God is the sun for the mind' p. 18.
} 
of the issues surrounding the use of metaphor : spatial, landscape and plant metaphors, the relation to allegory, and the emblem as a representation of its own communicative situation. ${ }^{5}$

\section{Mentis sol amor dei}

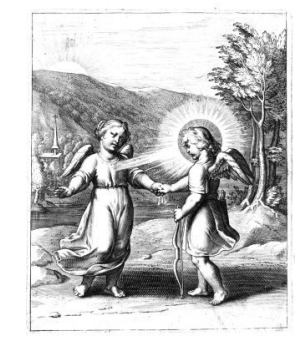

Figure 1 : Mentis sol amor dei, p. 19

Many of the metaphors that create the intellectual coherence of the book are clearly present in MeNTis SOL AMOR DEI (fig.1). First of all there is the light. The fullest statement of the metaphor structuring the emblem is given in the first quote, from Augustine: 'What the sun is to the senses, love is to the mind, and as the sun illuminates earthly things so that they may be seen, so God's love illuminates spiritual things'. The pictura shows the sun, and a beam of light emanating from Divine Love's nimbus and shining on the soul's heart. Metaphors of light are ubiquitous in Amoris Divini Emblemata. The Dutch and French epigrams mention the fruits born by nature under the influence of sunlight and compare these to the fruits of Divine Love. Imagery of fruits, of plant life, of trees, and therefore of agriculture, recurs throughout the book. Mario Praz severely criticised Vaenius for the bleakness and barrenness of his landscapes in Amoris Divini Emblemata, but in fact most pictures show vegetation - as this one amply does. ${ }^{6}$ And in the context of this book, each tree and each plant is proof of God's presence in the world.

In the pictura, there is a noticeable number of vertical lines : both the tree and the chapel's steeple pointing upwards, the steeple firmly towards the sun. The metaphors of up and down, high and low, heaven and earth, good and bad, again are omnipresent in picture and text. The church, furthermore, is not just there to point upwards. Its presence is also a reminder of the overriding importance of religion in man's life. Just as the presence of Cupid may turn a picture of a candle into a sign of the dangers of love, the presence of a church turns an indifferent landscape into a religious allegory. Another aspect of this allegory is water : in the context of Amoris Divini Emblemata, water may be compared to virtue, or to love ; in the pictures very often it seems to be related to the river of death -water that is to be crossed in order to reach a final destination. Hence also the importance of bridges.

Another aspect of metaphorical representation in Amoris Divini Emblemata prominently present in MENTIS SOL AMOR DEI is its allegorical embedding. The picture shows not just the metaphor, not just the illumination of the mind ; it also shows Amor Divinus and the soul in action. They are holding hands, which shows their intimacy; her body language seems to express her willingness to receive - the scene may even remind us of an annunciation, the soul like Mary gratefully accepting. In fact, the vernacular epigrams explain that the light of the sun helps the earth bear fruit. The spiritual fruits which Divine Love's light helps grow are

\footnotetext{
${ }^{5}$ I will not discuss each significant detail in the emblems that I mention. My intention is rather to draw attention to some of the lesser-noticed features of the book as a whole .

${ }^{6}$ M. Praz. Studies in Seventeenth-Century Imagery. 2nd. edition considerably increased (Roma, 1975), 134-138.
} 
'La vertu, le repos, la paix'. Even details like the soul's wings are significant, as one of the quotations interprets them as the love and faith that help the soul reach God.

Finally, I want to draw attention to a very pervasive parallelism in the emblems of Amoris Divini Emblemata: Divine Love illuminates spiritual things and in doing so illuminates the soul; and in a certain sense this relation between Divine Love and the soul mirrors the relation between the implied author of the emblem and its implied reader. The author illuminates the reader, just as Divine Love illuminates Anima. This will turn out to be a recurring feature in many emblems in the book and I will return to it at the end of the paper.

\section{Metaphor}

So what is a metaphor? Working as we do in the field of emblems, we are fortunately immune to the lures of theorists that consider metaphor to be a linguistic or literary phenomenon only. For the purposes of this investigation, I will consider metaphor to be a conceptual entity, consisting in the conventional association between two concepts, the tenor concept and the vehicle concept. The tenor is conceived in terms of the vehicle. You may recognise the tenor and vehicle terminology from the theories of I.A. Richards, ${ }^{7}$ with a cognitive twist based on Lakoff and Johnson. ${ }^{8}$ Usually a metaphor is based on an agreement or structural analogy between the concepts. The vehicle concept, with its surrounding conceptual structure, provides a schema which helps organise and form the tenor concept. ${ }^{9}$

The most important reason to view metaphors as primarily conventional associations between concepts is that metaphors typically occur in clusters : 'human being conceived of as a plant' may define such a cluster, leading to metaphors where stages of man's life may be compared to a plant's life cycle, or parts of his body to roots, branches, leafs. These metaphorical associations are indispensable for speaking and thinking about abstract matters.

The metaphors that appear in texts or images are examples of these conceptual metaphors. Parts of the vehicle's schema, as transferred to the tenor, will occur in the text and refer to the schema's original domain (love 'illuminates' the soul). Other schema constituents may tacitly contribute to the significance of the metaphorical statement.

Metaphors are thus primarily a tool for understanding the world. But the promotion of a certain understanding of the world may also be employed for other reasons. A metaphor may be used to convince, but also to make a promise, as in 'He will cover you with his feathers', or in order to exhort, as in 'be like a mirror without blemish'. I will refer to this aspect as the metaphor's usage mode.

In her book, Ms. Buschhoff mentions some of the metaphors that the opening emblems of Amoris Divini Emblemata create or activate. Some of those we already met in the description of MENTIS SOL AMOR DEI. The heavenly light of the opening emblem will return on every picture in the guise of the nimbus of Amor Divinus, and often also as the sun. Another powerful metaphor which the first emblems evoke is the concept of life as a journey. It is a metaphor with a particularly rich source schema, and it provides a particularly forceful example of metaphors coming in groups : a journey may have a purpose, there may be ambushes, you can get lost, one needs a car or other vehicle, a road to travel on, one may meet enemies or highwaymen, etcetera. We encounter each of these aspects in Amoris Divini Emblemata. And each road or path in picture or text, even if not the subject of explicit comment, will still contribute to the overall significance of the emblem and the book as a whole.

\footnotetext{
${ }^{7}$ I. A. Richards, The Philosophy of Rhetoric (New York, 1965).

${ }^{8}$ G. Lakoff, and M. Johnson, Metaphors We Live By (Chicago, London, 1980).

${ }^{9}$ N. Goodman. Languages of Art. An Approach to a Theory of Symbols (Indianapolis, 1976).
} 


\section{Superna respicit}

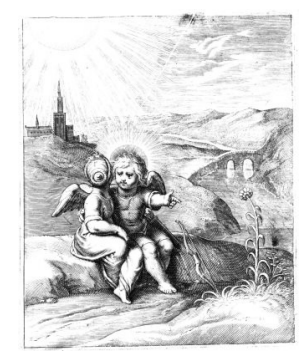

Figure 2 : Superna respicit, p. 39

The metaphors that I want to explore first are those of plant life and landscape. I will introduce them in a discussion of the well-known sunflower emblem from Amoris Divini Emblemata, Superna RESPICIT. ${ }^{10}$ The salient metaphor in SuPERNA RESPICIT (fig. 2) is the analogy between soul and sunflower. As the sunflower directs itself to the sun, so the soul should direct herself to God. The pictura shows the sunflower directing itself towards the sun, and thus contains the metaphor's vehicle. The metaphor's tenor is also present in the pictura, in an interesting way : the soul too is turned towards the sun. That is : a single image fragment (the sun) represents both the sun itself, and, through the 'God is sun'-metaphor, God. This is not mere convention: God is being compared to the sun because of a double similarity. As the French epigram states, both can be described as author or creator of earthly life, be it in very different senses, and as is stated in the Dutch epigram, both are providers of light, again in different senses.

But the pictura contains more than just the metaphor's vehicle and tenor : it also shows how Divine Love is pointing the soul towards the behaviour of the sunflower. Divine Love being the soul's guide on her journey, we can take this to be an exhortation to the soul to do as the sunflower does. The pictura therefore also contains what I have called the metaphor's usage mode.

The most interesting textual component of this emblem is the Augustine quote : 'But heaven and earth and everything that they contain, from all sides they say to me, that I should love thee, and they don't stop saying this to all...' This text turns the sunflower into a metonym for the created universe, and that which we can readily see that the sunflower does (that is, follow the sun, orient itself towards its creator) is asserted to be true for all created things. Conversely, this also allows us to look at the landscape that surrounds the main metaphorical objects as a bearer of significance. The recurring features of this metaphorical landscape are : vegetation, light, churches, water and bridges, and verticality.

Many of these metaphorical fields, such as those of vegetable life, provide fine examples of pre-existing analogy that Amoris Divini Emblemata could just take up. In fact, the second emblem in the book, INCIPIENDUM, already activates the plant metaphor : the texts quote the Song of Songs and state that winter is over, that a time of sweetness has come, and that flowers appear on the earth. The pictura shows these flowers, which the vernacular epigrams describe as the flowers of grace that should adorn our hearts.

There is one emblem where plant imagery appears as the central metaphor, and that is the emblem Aв UNO AMORE MULTA BONA. ${ }^{11}$ In this emblem, the texts present Love as the root of all good things : 'as many tree branches proceed from a single root, so too many virtues

\footnotetext{
10 '[He] looks upwards', p. 38.

11 'Many good things from one love', p. 60.
} 
proceed from a single love. And the branch of good work has no greenness, if it does not stay in the root of love'. The pictura shows the virtues (strength, faith, hope, etc.) being offered for display by the soul and love conjointly. They are framed by trees with prominent roots.

In other emblems, as in MENTIS SOL AMOR DEI, the virtues are not compared to branches, but to fruit. Elsewhere again, the virtues are the plants themselves, and love is no longer compared to the plant's root, but to the water that feeds the plant, as in IN SPIRITU SEMINAT. ${ }^{12}$ The French epigram says : 'Ainsi qu'en arrosant la plante / Elle s'accroist de iour en iour : / De mesme nostre foy s'augmente / Estant arrosée d'Amour.' The pictura shows Divine Love watering the plants that Anima has just sown.

The root can be metaphorically replaced by water, as both can be conceived of as an origin, which also connects to metaphors of sources and fountains. Water of course is necessary not just to plants, but to all living beings. The life-giving forces of water are a central subject in three other emblems, among which is Siтim ExTinguit. ${ }^{13}$ The water mentioned here is the water which, in a reference to John 4, quenches your thirst forever.

The metaphors of plants and water are interesting, because they lend themselves very well for background scenery. The same holds true for the high-low opposition. Many pictures contain hills or mountains, churches on hilltops, narrow roads leading uphill. One of the emblems that is most explicit in creating and exploiting an equivalence between high, up, heaven, the good on the one hand, and low, down, hell and evil on the other hand, is Conscientia Testis. ${ }^{14}$ The soul is toying with an arrow while she has to choose between the heavenly Jerusalem, on a mountain, a steep path leading uphill, and Babylon, on the plain ; Amor Divinus is standing up proudly, wings turned up, head erect, a young man raising the cross, while earthly love is smaller and bent, a baby boy with wings dejectedly downwards.

In almost all emblems of Amoris Divini Emblemata, one ore more of these fundamental metaphors helps set the scene for the emblem's central metaphor. And even though only the vehicle of these surrounding metaphors is present in the images, one can safely say that their presence is no coincidence. A good final example is AMOR RECTUs ${ }^{15}$, where the picture shows light, water, trees, a hill (meaningful verticality) and a church. There is of course no simple one-to-one translation, like 'water always means a or b or c', but what the background elements do achieve is to present the landscape as meaningful and charged with moral tensions.

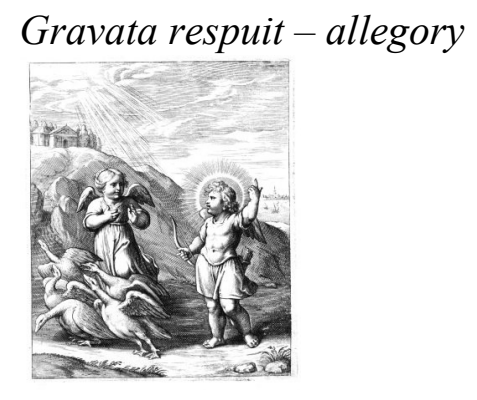

Figure 3 : Gravata respuit, p. 53

The second aspect of metaphor in Amoris Divini Emblemata that I want to discuss is the question of its relation to allegory. What I will try to show is how deeply the allegorical and the metaphorical are intertwined in this book. As we did for the metaphor, we should realize

\footnotetext{
12 ' $[\mathrm{He}]$ sows in the spirit', p. 50.

13 ' $[\mathrm{He}]$ quenches thirst', p. 84.

14 'Conscience is witness', p. 110.

15 'Righteous love', p. 14.
} 
that allegory is not just a trope. Allegory is not a painter's trick, invented to circumvent the difficulties of representation of abstract entities. Abstract entities are personified because, as Lakoff and Johnson write '[Personification] allows us to comprehend a wide variety of experience with nonhuman entities in terms of human motivations, characteristics and activities'. ${ }^{16}$ This will become clear once we look at the personifications in Amoris Divini Emblemata : in the first place of course Divine Love and the soul themselves, but also Nature, Hope, and the virtues.

A good example of the allegorical embedding of metaphor is Gravata RESPUiT. ${ }^{17}$ Gravata RESPuit (fig. 3) contains two main metaphors : the heavy geese that, as the text explains, are unable to fly, and the metaphor of 'up = good' which Amor Divinus draws attention to. The geese are weighed down by their useless fat. And as a quote from Augustine makes clear: 'A soul in the bonds of earthly love has as it were meat on her wings and cannot fly, but once she is cleansed of that impure worldly desire, she spreads her wings and flies'.

As we already saw in the context of MENTIS SOL AMOR DEI and SUPERNA RESPICIT, the presence of the allegorical figures of Amor Divinus and the soul makes it possible for the picture to state the preferred attitude towards the metaphorical object. In the sunflower emblem, Amor Divinus pointed the soul at the sunflower. In Mentis sol AMOR DEI, we saw the soul accepting and taking to heart the illumination by Amor Divinus. In GRAVATA RESPUIT there is a complex interaction. Amor Divinus points upwards, for the soul's benefit, as appears from his looking at her. She is looking at him, showing with her right hand that she is taking his message to heart, with her left hand rejecting the example given by the geese.

The allegorical figures therefore indicate what I have called the usage mode of the metaphor. Anima makes clear the geese are to be rejected, Amor Divinus shows heaven is to be preferred. The reader who witnesses this complex communication between the protagonists is of course also the ultimate destination of this communication. Very often the pictures employ the fixed and so-called allegorical attributes of Divine Love (the nimbus, the wings, the quiver, bow and arrows), and to a lesser extent those of the soul, in order to highlight or add a shade of significance in the concept of Divine Love or soul. In GRAVATA RESPUIT the wings of the soul are essential to contrast her ability to rise above the earth with the geese's inability to do so. In the case of Divine Love, the pictures often use his bow with humorous effect. $^{18}$

The other allegorical figures in the book are similarly employed within a metaphorical context. The personification of Nature in the emblem NATURAM VINCIT ${ }^{19}$ is clearly an allegory, in the sense of a personification of an abstract entity by a woman in a state of partial undress. Nature is being personified ${ }^{20}$ in order to make her into an antagonist, someone of doubtful morals that may and should be pushed away. Personification is a metaphor because it allows us to think about the abstraction in terms of a person, and thus for instance as someone that may need to be vanquished. Similar remarks might be made about Hope, in ANIMÆ SPES OPTIMA NUTRIX. ${ }^{21}$ Hope with her anchor is not a purely conventional sign : her suckling provides the soul with essential (metaphoric) nourishment, and their intimacy and the proximity of Divine Love add a meaning far beyond the merely conventional. Even where allegory is at its most conventional, the group of virtues in MICAT INTER OMNES AMOR VIRTUTES, ${ }^{22}$ these are not just representations of the virtues. The figures' portrayal intimates, for instance, that they are subservient to Love, and that they belong together. The directions of their eyes may indicate

\footnotetext{
${ }^{16}$ Lakoff and Johnson, op. cit. 33.

17 ' $[\mathrm{He}]$ rejects heavy things', p. 52.

${ }^{18}$ For instance in Odit moras ('[Love] hates delay', p. 68) or Odit timorem ('[Love] hates fear', p. 106).

19 ' $[\mathrm{He}]$ conquers Nature', p. 46.

${ }^{20}$ As the many-breasted Diana of Ephesus.

21 'Hope is the best foster mother for the soul', p. 66.

22 'Love shines among the other virtues', p. 88.
} 
that they rely on heaven for their strength. Being bona fide personifications, they are fully dressed. They are illuminated by the light shining from heaven.

Let me recapitulate what I have said up to now. An investigation into the use of metaphor in Amoris Divini Emblemata shows (1) that because of the shared metaphors the book is very much a coherent whole, perhaps more so than has been previously thought ; (2) that the embedding of a metaphor in an allegorical setting creates the possibility for communicating complex attitudes towards the metaphorical objects ; and (3) that because of (1) and (2) the density of meaning in the pictures may be larger than hitherto recognized.

\section{Author and reader}

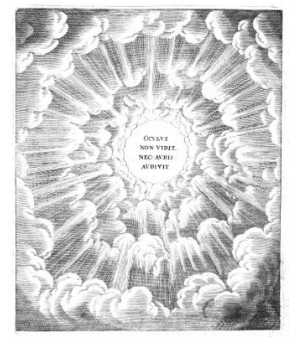

Figure 4 : Deus ante omnia amandus, p. 9

To conclude, I want to return to the issue of the relationship between Amor Divinus and Anima, which I will approach by discussing the only picture from which they are absent, the pictura of the first emblem in the book, Deus ANTE OMNIA AMANDus (fig. 4). ${ }^{23}$ We see a glory of clouds, with the words 'Oculus non vidit, nec auris audivit. ${ }^{24}$ This bible quotation is taken up in the epigrams to convince the reader that he should love God, and that God will give something in return that the eye has not seen and the ear has not heard.

Margit Thøfner, in her article on Theresian mysticism in Amoris Divini Emblemata, ${ }^{25}$ considers these words to be only apparently anti-sensory, but what she does not take into account is the fact that it is in the picture of the very first emblem, in the most prominent place imaginable, that Vaenius reverts to using text rather than image. Even quite apart from the contents of the text, which seems an unequivocal repudiation of the senses, to me this is a very clear statement that the senses by themselves are untrustworthy and need guidance. What this emblem book sets out to do, then, is not just to show and explain metaphorically significant objects or actions, but also to thematize the process of guidance ; which, I suggest, is why Amor Divinus and Anima are there in the first place, and why there is a natural similarity between Amor Divinus and the implied author on the one hand, and Anima and the implied reader on the other hand.

In some of the emblems that we have seen, this process is very clear : Divine Love indicates the sunflower to the soul, Divine Love points her towards heaven, Divine Love points at the water she is drawing from the well, ${ }^{26}$ and on each of these occasions, he draws her attention to the symbolic meaning of the objects - just as, by this very token, the author does to the reader. In other cases there is no symbolic object that Amor Divinus draws attention to, but still he is teaching, illuminating, enriching - all things that, metaphorically, the emblem itself accomplishes.

\footnotetext{
23 'God is to be loved above all', p. 8.

24 'The eye has not seen, nor the ear heard', 1 Corinthians 2:9.

${ }^{25}$ Margit Thøfner, “"Let your desire be to see God” : Teresian Mysticism and Otto van Veen's Amoris Divini Emblemata', Emblematica, 12 (2002), 83-103.

${ }^{26}$ in Sitim EXTINGUit.
} 


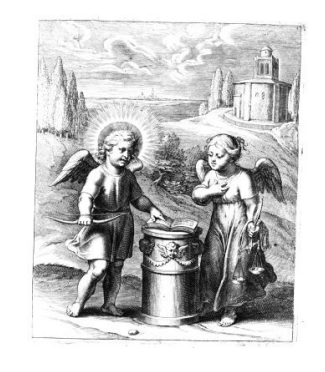

Figure 5 : Virtus character amoris, p. 35

A very interesting emblem in this context is VIRTUS CHARACTER AMORIS, ${ }^{27}$ as it shows the whole process (fig. 5) : Divine Love points out a passage in a book, the soul takes that to heart, and as a result, she is '[D]e bonnes œuures reuestuz', as the French epigram says, clothed in the virtues (bridle, scales, mirror) that the inscription states are the proof of Love. Now the book, presumably, is primarily the Bible, but I think we are justified in also thinking of the emblem book, which would equate Divine Love with the emblem's author, Anima with the emblem's reader.

Similarly, in Sollicitus EsT ${ }^{28}$ Divine Love holds up the Gospel to the attentive soul, while in the background a woman uses a mirror to inspect her hairdo. The background scene glosses the Gospel as providing a mirror to the soul, and the emblem texts concur. Van Veen quotes Gregory : 'Holy Scripture is placed as a mirror before the eyes of the mind so that we see there our inner face'. Again, to provide a mirror to the soul is also what this very emblem does, and in that sense, the emblem pictures itself, and the communicative situation in which it functions. Thus, the metaphors in Amoris Divini Emblemata do not just represent the properties of divine love, their avowed tenors. Ultimately, they may also mirror the book's aspiration of providing guidance to the soul.

To us, however, these mirrors cannot pretend to be without distortion. As many have said, the soul in Amoris Divini Emblemata represents the book's reader. However, to some extent this is no more than a rhetorical manoeuvre. The soul as being depicted in the pictures is not just any reader. In her willingness to accept the teachings proffered in the book, in her ostentatious display of agreement with Divine Love, her representation is every inch as much calculated to convince the actual reader as is that of Divine Love. In some respects, rather than represent the reader, Anima is playing the reader, she is pretending to be the reader, in order to tell an actual reader what to do. But that is really the subject for another paper.

\footnotetext{
27 'Virtue is the mark of love', p. 34.

28 ' $[\mathrm{He}]$ is wakeful', p. 114.
} 
Biographical info

Peter Boot studied mathematics and Dutch literary history at the universities of Leiden and Utrecht. He helped create the Emblem Project Utrecht. He is employed as a researcher and humanities computing consultant at the Huygens Instituut (The Hague). At Utrecht University he works on a PhD thesis on digital emblem semiotics which will focus on Van Veen's Amoris Divini Emblemata.

\section{List of proper names}

Otto van Veen

Otho Vaenius, see Otto van Veen

Augustine of Hippo

Gregory the Great

\section{Captions to the illustrations}

Figure 1 : Mentis sol amor dei, p. 19

Figure 2 : Superna respicit, p. 39

Figure 3 : Gravata respuit, p. 53

Figure 4 : Deus ante omnia amandus, p. 9

Figure 5 : Virtus character amoris, p. 35 